
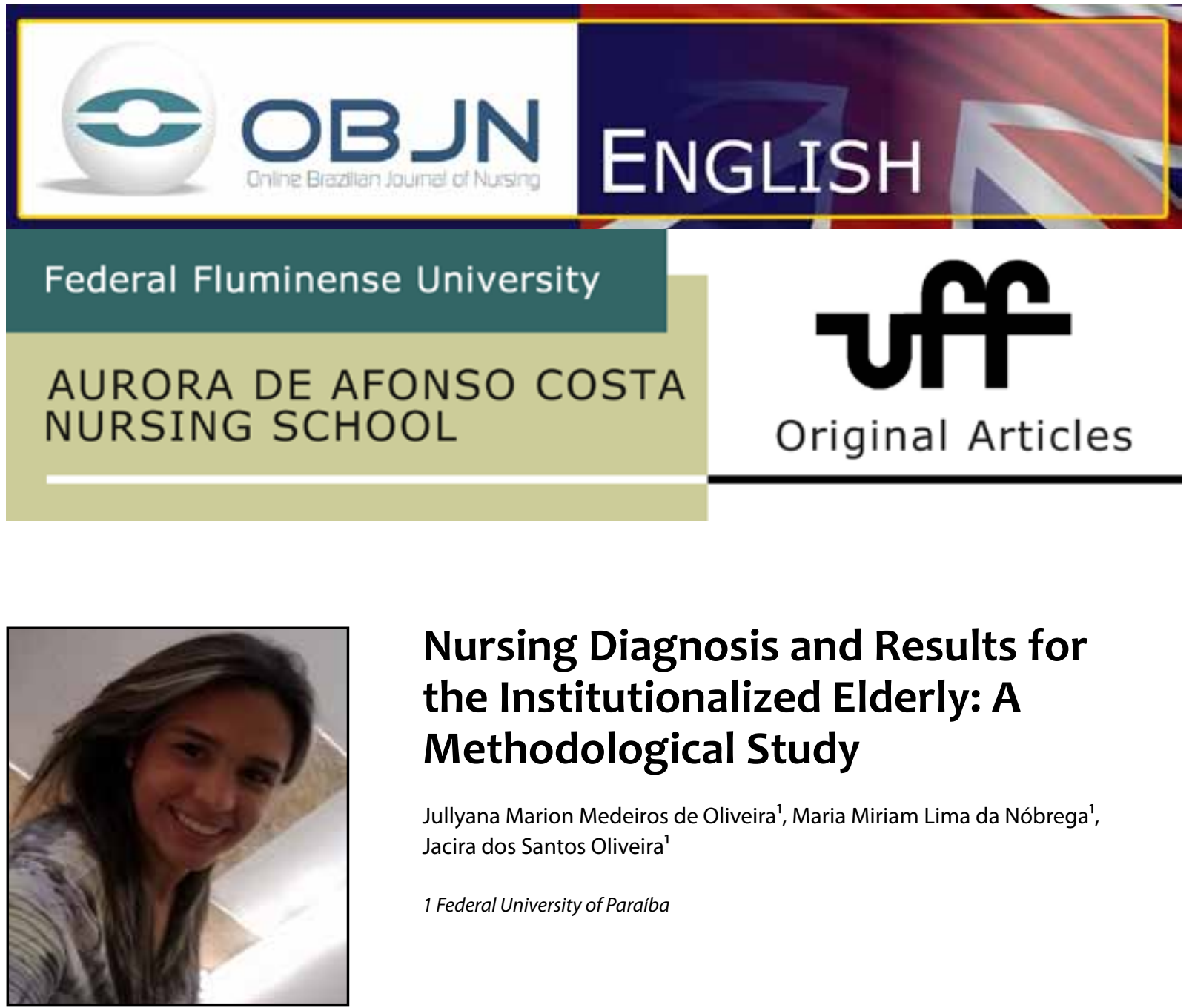

\title{
Nursing Diagnosis and Results for the Institutionalized Elderly: A Methodological Study
}

\author{
Jullyana Marion Medeiros de Oliveira', Maria Miriam Lima da Nóbrega', \\ Jacira dos Santos Oliveira' ${ }^{1}$ \\ 1 Federal University of Paraíba
}

\begin{abstract}
Aims: To identify nursing practice focuses and create statements in terms of the diagnoses and results of the International Classification for Nursing Practice (ICNP ${ }^{\circ}$ ) for the institutionalized elderly. Method: This is a methodological study based on Horta's theory, carried out in a long term care facility for the elderly (LTCF), using the cross-mapping technique and content validation. Eighty three (83) elderly individuals participated in the study. Results: We identified 192 focuses of nursing practice and the construction of 129 statements of diagnostics and results. According to the cross-mapping, we can highlight that 60 statements were constant and 69 were not listed in the ICNP', version 2013. Conclusion: The 192 focuses of nursing practice that have been identified in the health assessment of the institutionalized elderly allowed the construction of 129 statements of diagnoses and results. These findings make it possible to implement the process in order to systematize nursing practice in these environments.
\end{abstract}

Descriptors: Nursing; Aged; Homes for the Aged; Nursing Diagnosis. 


\section{INTRODUCTION}

For the success of health maintenance and well-being of individuals, nursing assistance must be solidified by systematic actions aimed at full, humanized and individualized care of the person cared for through the practice of Nursing Assistance Systematization (NAS) by means of the nursing process ${ }^{(1)}$.

In this context, it is believed that the nursing care aimed at the institutionalized elderly should be accomplished through systematized actions that utilize the nursing process, directing care actions to the affected needs with the support of nursing theories and the use of classification systems ${ }^{(1,2)}$.

The nursing care based on the comprehensive health care of institutionalized aged people should be directed to the identification of focuses in terms of nursing practice. In this study, the focuses are conceptualized as basic human needs affected, which are identified through the survey of nursing history empirical data(3).

The clinical reasoning of nursing focuses allows the construction of diagnostics by means of Language Standardization Systems - in this case it is the International Classification for Nursing Practice (ICNP ${ }^{\circ}$ ). The ICNP ${ }^{\circ}$ is presented as a universal language terminology which has its starting point in 1989, and allows the construction of statements of diagnoses, interventions and nursing outcomes for specific populations ${ }^{(4)}$.

However, it is notable that the practice of systematizing nursing actions in long term care facilities (LTCF) for the elderly is incipient and/ or little used, which can result in care without continuity and achievement of goals, and it may compromise the health of the institutionalized elderly.

Therefore, this study is significant as it proposes a technological resource that aims to implement the nursing process, and it brings personalized and comprehensive care from the perspective of an active and healthy aging process in the institutionalized elderly, as well as proposing a solidified framework of assistance in terms of scientific knowledge, and an autonomous practice.

Thus, the research aims to answer the following questions: what are the focuses of nursing practice that are identified in the health assessment of older people living in a LTCF? Which statements of diagnoses and results can be constructed from the nursing practice focuses?

This research aimed to identify the nursing practice focuses in the health assessment of aged people and create statements of diagnoses and results of ICNP ${ }^{\circ}$ on the institutionalized elderly.

\section{METHOD}

This is from a methodological study resulting from a Masters dissertation with the use of a cross-mapping technique and content validation by experts. The study was developed in a long term care facility (LTCF) for seniors in the city of Natal/RN. The survey was conducted from May to June 2014 and it included 83 institutionalized elderly, according to the inclusion and exclusion criteria respectively. As inclusion criteria, individuals must be institutionalized, over 60 years of age or older and reside in the LTCF under study. The exclusion criteria are: non-institutionalized individuals or persons under the age of 60 , or those who are not residents in the local institution under study.

The research was conducted in four stages: $1^{\text {st: }}$ Identification of nursing practice focuses on the elderly living in the LTCF.

$2^{\text {nd: }}$ Construction of statements of diagnoses and results. 
$3^{\text {rd }}$ : Cross-mapping of concepts created with the ICNP 2013 version.

$4^{\text {th }}$ : Content validation of statements of nursing diagnoses and results by experts.

The 1st step was the implementation of the nursing history. We used a validated and adapted $^{(5)}$ assessment tool for the health of the institutionalized elderly. After using three pilot tests, we identified the need to adapt the tool to the institutional reality and health of those surveyed. This stage was performed in 20 meetings with 83 seniors in an average time of one hour for each implemented history. The data to complement the research were sought in the records of the surveyed elderly, as well as directly with the local nursing staff and social assistance.

The empirical data collected from the elderly were organized in tables in the Microsoft Word software, and the mapping of the nursing practice focuses relevant to each elderly person was carried out. We used the categorization of focuses based on the basic human needs of Horta's conceptual model ${ }^{(3)}$.

The 2 nd stage was accomplished by the construction of diagnoses using empirical indicators and the ICNP version 2013 published in January ${ }^{(6)}$. Initially we did the clinical evaluation of the individual nursing histories related to the basic human needs affected.

After that, we constructed the statements of diagnoses based on the recommendations of ISO 18.104/03 and the guidelines adopted by the $\mathrm{CIE}^{(7)}$ - which used an axis term "Focus" and the other axis term "Judgment" - and also in some statements the use of terms of other axes where needed.

In this study, the term "nursing diagnosis and result" was used as a single expression for the two elements of nursing practice; therefore, the same recommendations of ISO 18.104/03 guidelines adopted by the CIE are used in order to construct the statements. The differentiation between the statements of diagnoses and results is present in the judgement of clinical reasoning by the nurse before the status, the problems and/or needs (diagnosis) of the patients, or if this is the response after the implementation of interventions (results) ${ }^{(7)}$.

To complete the stage, a spreadsheet of the predefined concepts of nursing diagnoses was built in Microsoft Excel (Office 2007). The diagnoses were adjusted in relation to the spelling, based on the statements contained in ICNP ${ }^{\circ}$ version 2013.

In stage 3, we carried out cross-mapping with the pre-combined concepts of the version 2013 of the $\operatorname{ICNP}^{\circ}(6)$, using data exportation. The mapping was done by means of exporting the list of statements of diagnoses and results created in Microsoft Excel (Office 2007) for Microsoft Access for Windows. From the mapping technique results, originated two lists and statements which were classified as constant or non-constant in ICNP'.

The results that were considered non-constant were judged by the criteria proposed by Leal ${ }^{(8)}$ : Similar (with significance equal to the ICNP', but written differently); more comprehensive (wider meaning than the pre-combined concept existent in ICNP'); more limited (less broad meaning than the pre-combined concept existent in ICNP $^{\circ}$ ); or no agreement (divergent from pre-combined concepts existent in ICNP').

The $4^{\text {th }}$ stage dealt with the validation of the diagnoses and nursing results created. The content validation technique was used by nursing specialists who provide or have provided assistance to the institutionalized elderly. Nine nurses who were selected through curriculum analysis by means of the Lattes Platform participated in this stage. They answered a questionnaire with a built statements list.

The nursing diagnoses and results were validated by using the Content Validity Index 
$(\mathrm{CVI})^{(9)}$ in relation to the relevance or irrelevance of the statements for the use of nursing practice with the institutionalized elderly. The statements that reached $C V I \geq 0.8$ were considered valid.

After validation, the statements that had scores greater than or equal to 0.8 , and considered valid, underwent a further review and analysis in compliance with the suggestions of experts and researchers involved. This review resulted in the elimination and modification of some of these statements, as we observed some textual inconsistencies and the need to exchange them for other nursing diagnoses which are considered more comprehensive.

The research was approved by the Research Ethics Committee of the Center for Health Sciences of the Federal University of Paraíba, under the protocol No. 081/14 and CAAE 27593814.1.0000.5188. The research procedures involving human subjects were followed in order to preserve the physical, moral and social integrities of the subjects involved ${ }^{(10)}$.

\section{RESULTS}

In the characterization of the institutionalized elderly, we observed that $74.8 \%$ are aged between 70 to 89 years, $67.4 \%$ are female, $47 \%$ are single, $82 \%$ have low level of education and $54 \%$ present dependence III level. These data are shown in Table 1.

Table 01 - Characterization of older persons residing in long-stay institutions for Seniors. João Pessoa, 2014.

[TABLE 1]

Source: authors.

In the identification of empirical indicators, 192 focuses of nursing practices were extracted. Of these 113 were categorized as physiological needs, 74 as psychosocial needs and 5 as psychospiritual needs. It was observed that the most frequent physiological needs (23.8\%) were those of security and environment, and amonsgt the psychosocial needs, the need for love, acceptance and self-fulfillment presented a higher frequency (25.6\%). The graphic 01 shows these data.

Graphic 01 - Distribution of nursing practice focuses on Basic Human Needs. João Pessoa, 2014.

\section{[GRAPHIC 1]}

\section{Source: authors.}

The study resulted in 129 nursing diagnoses and results being constructed. Regarding the mapping technique, of the 129 statements of nursing diagnoses and results constructed, 59 were classified as constant and 61 as non-constant in ICNP'. The 61 statements considered non-constant underwent the process of analysis for similarities and differences. Result: one similar statement which, when considered appropriate in terms of the terminology, was classified as a constant statement with the ICNP ${ }^{\circ}$ version; 18 statements were considered more comprehensive; 2 statements were considered more restricted; and 49 were without an agreement. There was a total of 60 constant and 60 non-constant statements in ICNP' version 2013.

Of the 129 statements created, 86 were validated, corresponding to $67 \%$ of statements. However, with the review carried out concerning the semantics of the statements created, and the need to include some less comprehensive diagnostics in the most comprehensive ones, 14 statements were eliminated from a total of 72 statements of nursing diagnoses and results valid for nursing practice with the institutionalized elderly. Forty-six (46) were categorized as psycho-biological needs and 26 as psychosocial needs, as described in Table 01. 


\section{DISCUSSIONS}

When analyzing the results, we noticed that the characterization profile of the elderly people of this research are in line with other studies $^{(11,12)}$ that have been developed in other LTCFs. It appears that the institutionalized elderly are characterized as long-lived and, in addition, the feminization phenomenon of aging is noticeable. Regarding marital status, it is observed that most individuals are single, a fact that is possibly due to family fragility, marked by the nuclear family.

As for education, the low level of education found may compromise the self-care conditions of the elderly, making them more dependent.

The nursing practice focuses presented the psychobiological needs with emphasis on the need for physical safety and environment with greater expressiveness. This finding is supported by the considerations proposed by Maslow's pyramid, which regards physiological and safety needs as the most vital to humans, and required the remedying of other details under hierarchically superior satisfaction levels ${ }^{(3)}$.

Other studies also showed similar results in the affected needs. Psychobiological needs referred to by the indicators are body care, mobility, elimination, nutrition, circulation, neurological regulation, safety and physical integrity. Psychosocial needs are also relevant and have the following indicators: communication, cognition, love, acceptance, self-fulfillment, emotional security and gregariousness ${ }^{(11.13)}$.

It is observed that the focuses of nursing practice become noticeable in terms of the peculiarities of aged people in addition to the characteristics of the population who age in institutionalized environments. These specifics are challenges for the professional nurse who should be able to interpret the singularities of the health conditions of the elderly and the care

Picture 05 - Utterances in terms of nursing diagnoses and results constructed and validated according to the Basic Human Needs. João Pessoa, 2014.

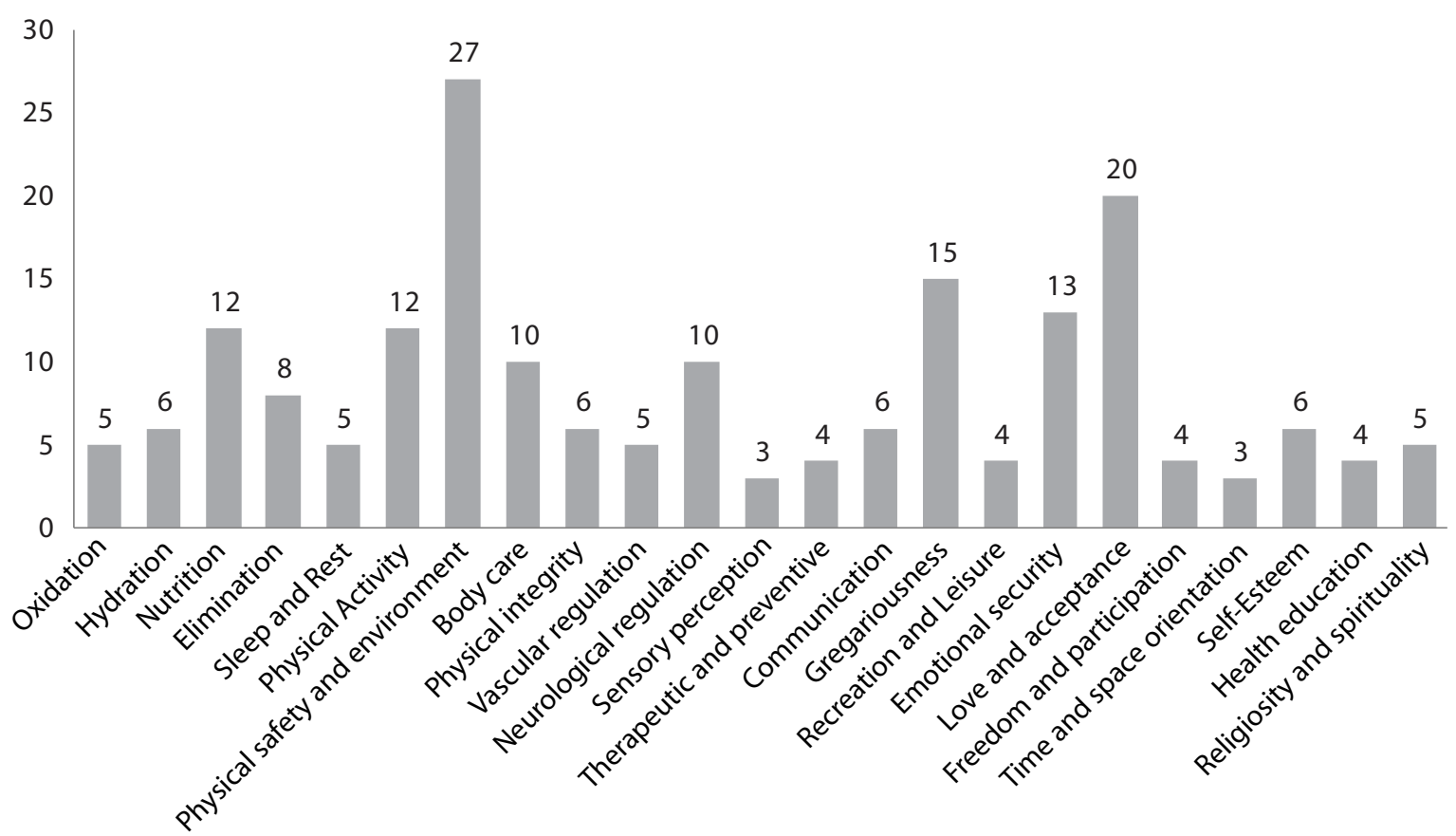

Source: authors. 
Picture 05 - Utterances in terms of nursing diagnoses and results constructed and validated according to the Basic Human Needs. João Pessoa, 2014.

\begin{tabular}{|c|c|}
\hline BASIC HUMAN NECESSITIES (BHN) & \multirow{2}{*}{ NURSING DIAGNOSTICS AND RESULTS } \\
\hline PSYCHO-BIOLOGICAL NECESSITY & \\
\hline Oxidation & 1. Gas Exchange, Impaired; \\
\hline \multirow[t]{2}{*}{ Hydration } & 2. Liquid Intake, Impaired; \\
\hline & 3. Liquid Intake, Effective; \\
\hline \multirow[t]{5}{*}{ Nutrition } & 4. Low Weight; \\
\hline & 5. Risk of Nutrition, Poor; \\
\hline & 6. Obesity; \\
\hline & 7. Weight, Effective; \\
\hline & 8. Nutritional Condition, Positive; \\
\hline \multirow[t]{5}{*}{ Elimination } & 9. Urinary Incontinence; \\
\hline & 10. Urinary Infection Risk by Using a Bladder Delay Probe; \\
\hline & 11. Intestinal Incontinence; \\
\hline & 12. Constipation; \\
\hline & 13. Impaction; \\
\hline \multirow[t]{2}{*}{ Sleep and rest } & 14. Sleep and Rest, Impaired; \\
\hline & 15. Sleep and Rest, Effective; \\
\hline \multirow[t]{7}{*}{ Physical activity } & 16. Physical Mobility, Impaired; \\
\hline & 17. Activity Intolerance; \\
\hline & 18. Deambulation, Impaired; \\
\hline & 19. Disuse Syndrome Risk; \\
\hline & 20. Physical Activity Behavior, Impaired; \\
\hline & 21. Deambulation, Effective; \\
\hline & 22. Effective Tolerance to Activity; \\
\hline \multirow[t]{3}{*}{ Physical safety and environment } & 23. Tobacco Abuse; \\
\hline & 24. Falling Risk; \\
\hline & 25. Pressure Ulcer Risk; \\
\hline \multirow[t]{5}{*}{ Body and environmental care } & 26. Ability to Execute Self-care, Impaired; \\
\hline & 27. Oral Hygiene, Impaired; \\
\hline & 28. Hygiene, Impaired; \\
\hline & 29. Ability to Execute Self-care, Positive; \\
\hline & 30. Hygiene, Effective; \\
\hline \multirow[t]{5}{*}{ Physical integrity } & 31. Pressure Ulcer; \\
\hline & 32. Diabetic Ulcer; \\
\hline & 33. Arteriovenous Ulcer Risk; \\
\hline & 34. Skin Integrity, Impaired; \\
\hline & 35. Fracture; \\
\hline \multirow[t]{3}{*}{ Vascular regulation } & 36. Peripheral Tissue Perfusion, Impaired; \\
\hline & 37. Hypertension; \\
\hline & 38. Risk of Unstable Blood Glucose; \\
\hline \multirow[t]{2}{*}{ Neurological regulation } & 39. Cognition, Impaired; \\
\hline & 40. Mental Activity, Impaired; \\
\hline
\end{tabular}

Oliveira JMM, Nóbrega MML, Oliveira JS. Nursing Diagnosis and Results for the Institutionalized Elderly: A Methodological Study . Online braz j nurs [internet] 2015 Mar [cited year month day]; 14 (2):110-20. Available from: http://www.objnursing. uff.br/index.php/nursing/article/view/5151 


\begin{tabular}{|c|c|}
\hline \multirow[t]{4}{*}{ Sensory perception } & 41. Ability to Seeing, Impaired; \\
\hline & 42. Musculoskeletal Pain; \\
\hline & 43. Acute Pain; \\
\hline & 44. Pain, Chronic; \\
\hline \multirow[t]{2}{*}{ Therapeutic and preventive } & 45. Ability to Manage the therapeutic regimen, Impaired; \\
\hline & 46. Ability to Manage the therapeutic regimen; \\
\hline \multicolumn{2}{|l|}{ PSYCHOSOCIAL NECESSITY } \\
\hline \multirow[t]{4}{*}{ Communication } & 47. Verbal Communication Impaired; \\
\hline & 48. Expressive Aphasia; \\
\hline & 49. Verbal Communication, Effective; \\
\hline & 50. Communication, Effective; \\
\hline \multirow[t]{6}{*}{ Gregariousness } & 51. Social Isolation; \\
\hline & 52. Socialization, Impaired; \\
\hline & 53. Loneliness; \\
\hline & 54. Family Process, Impaired; \\
\hline & 55. Socialization, Effective; \\
\hline & 56. Family Process, Effective; \\
\hline Recreation and Leisure & 57. Deficit of Leisure Activities; \\
\hline \multirow[t]{4}{*}{ Emotional security } & 58. Sadness; \\
\hline & 59. Depression Risk; \\
\hline & 60. Fear; \\
\hline & 61. Anxiety; \\
\hline \multirow[t]{4}{*}{ Love / Acceptance } & 62. Link Elderly-Family, Impaired; \\
\hline & 63. Link Senior-Caregiver, Impaired; \\
\hline & 64. Denial of the Institutionalization Process; \\
\hline & 65. Link Elderly-Family, Effective; \\
\hline \multirow{2}{*}{$\begin{array}{l}\text { Self-esteem, self-confidence and self- } \\
\text {-respect }\end{array}$} & 66. Low Self-Esteem; \\
\hline & 67. Self-esteem, Positive; \\
\hline Freedom and participation & 68. Coping with the Institutionalization Process, Positive; \\
\hline Time and space orientation & 69. Disorientation; \\
\hline \multirow[t]{3}{*}{ Health education and learning } & 70. Learning Capacity, Impaired; \\
\hline & 71. Readiness to Learn; \\
\hline & 72. Knowledge in terms of Health and Treatment, Effective. \\
\hline
\end{tabular}

Source: authors.

needs grounded in gerontological and geriatric knowledge through a global assessment and clinical reasoning, for a possible standardized nursing language in the care of the institutionalized elderly ${ }^{(14)}$.

As a result of this study, it is observed that the needs for elimination, physical activity and physical integrity showed the largest number of nursing diagnoses and outcomes created, which may possibly allow the appearance of other problems and the presentation of new diagnoses when identified. As an example we can mention impaired physical mobility, which is categorized within the need for physical activity and makes the elderly prone to health problems that may lead them to develop more specific needs, thus

Oliveira JMM, Nóbrega MML, Oliveira JS. Nursing Diagnosis and Results for the Institutionalized Elderly: A Methodological Study . Online braz j nurs [internet] 2015 Mar [cited year month day]; 14 (2):110-20. Available from: http://www.objnursing. uff.br/index.php/nursing/article/view/5151 
directing them to the following diagnoses: risk of falls and impaired ability to perform self-care.

Moreover, the elderly are concentrated in the psychobiological needs, expressing themselves in care needs that are possibly linked to problems arising from anatomical and physiological manifestations of the aging process, but also of senility processes that favor comorbidities.

Regarding the need for elimination in the elderly, it is observed that studies ${ }^{(12,15)}$ directed to the construction and/or identification of diagnoses present urinary and bowel incontinence as a common problem among institutionalized elderly and that this problem affects the quality of life and socialization of these individuals.

The need for physical activity in the elderly is often linked to comorbidity standards that limit the functional capacity and make the elderly more prone to dependence on care and the process of institutionalization. Therefore, it is necessary to regulate the practice of physical exercises for strengthening the muscles so they may experience an active aging process ${ }^{(16)}$.

On the need for physical integrity, a study shows that, among the nursing diagnoses observed in the elderly in other studies, disorders in terms of skin integrity are among the most prevalent problems. This is due to common issues of the physical structure of the skin of the aging person, such as: decreased elasticity, turgor and the skin's ability to act as a barrier predisposing it to the appearance of lesions, as well as other physical characteristics of the individual: low weight, bony prominences, obesity, vascular and angiographic morbidities, among others ${ }^{(17)}$.

Therefore, it is observed that studies such as this show the benefits, in terms of the practice of construction of nursing diagnoses, for specialized areas of care. As a result of research that deals with the topic currently under study, it is noticeable from the results that nurses acquired scientific and documental support for nursing actions and greater visibility of nursing ahead other professions. In relation to being assisted, one can see comprehensive and quality care. Therefore, research that develops such practices accumulates results that enable their integration, supporting the decisions of nurses in terms of clinical focuses in distinct and specific $\operatorname{areas}^{(18,19)}$.

The survey suffered limitations regarding access to the personal and health information of some seniors, since on the occasions that it was not possible to identify the information by investigating it with the elderly directly, the information was sought in medical records and many of these records were incomplete, so it was necessary to refer to members of the local nursing and social assistance staff. There were also problems in the collection of data in terms of the process used. This fact possibly restricted the identification of some nursing practice focuses.

\section{CONCLUSION}

The practice of systematizing nursing care actions for the institutionalized elderly is possible in LTCF environments, and in this research 192 focuses were identified.

Still, it was possible to create 129 statements of specific nursing diagnoses for the institutionalized elderly, including 72 validated statements. This data may eventually contribute to the expansion and strengthening of terminology, to a practice with a comprehensive and individualized care and to the scientific basis of nursing actions, autonomy and professional recognition.

With the predominance of the most affected psychobiological needs presented between the identification results of nursing practice focuses and the construction of diagnoses, we understand that these can lead to greater com- 
mitment, in terms of the health of the institutionalized elderly in a hierarchical form, since these are considered vital to human homeostasis.

Therefore, there needs to be greater awareness by the nursing staff in order to direct actions more carefully regarding care in the prevention of adverse events in the health promotion and rehabilitation of the relevant needs in the pursuit of a healthier and more active aging process.

We also believe that the process of caring for the institutionalized elderly must be focused on systematic actions based on gerontological knowledge, even if the practice is permeated by obstacles and challenges. We perceive the need for assistance built on pillars of theoretical and philosophical knowledge of nursing, involving technological resources and theories for a quality individualized care that brings autonomy and scientism.

We hope that this study may contribute to the effectiveness of the organization of this practice and also that we can contribute a terminological subset of ICNP ${ }^{\circledR}$ to the specialized area of nursing care for the institutionalized elderly from these results in order to promote the continuity of this study.

\section{REFERENCES}

1. Silva, BT, Santos SC. Cuidados aos Idosos institucionalizados- opiniões do sujeito coletivo enfermeiro para 2026. Acta Paul Enferm [Internet] 2010 [cited 2013 out 28]; 23(6): 775-81. Available from: http://www.scielo.br/pdf/ape/v23n6/10.pdf

2. Mattos CMZ, Garces SBB, Costa FTL, Rosa CB, Brunelli AV, Hansen D. Processo de Enfermagem aplicado a idosos com alzheimer que participam do projeto estratégias de reabilitação. Estud. interdiscipl. Envelhec [Internet] 2011 Dec [cited 2013 Mar 08];16(esp.):433-447. Available from: http://www.seer.ufrgs.br/RevEnvelhecer/article/ view/17921
3. Horta WA. Processo de enfermagem . Rio de Janeiro: Guanabara Koogan; 2011.

4. Garcia TR, Nóbrega MML. A terminologia CIPE ${ }^{\circledR}$ e a participação do Centro CIPE ${ }^{\circledR}$ brasileiro em seu desenvolvimento e disseminação. Rev Bras Enferm [Internet] 2013 Sep [cited 2013 out 28]; 66(esp):142-50. Available from: http://www. scielo.br/pdf/reben/v66nspe/v66nspea18.pdf

5. Ribeiro RC, Marin HF. Proposta de um instrumento de avaliação da saúde do idoso institucionalizado baseado no conceito do Conjunto de Dados Essenciais em Enfermagem.Rev Bras Enferm [Internet] $2009 \mathrm{mar} / \mathrm{abr}$ [cited 2012 Ago 17]; 62(2): 204-12. Available from: http:// www.scielo.br/pdf/reben/v62n2/a06v62n2. pdf

6. International Council of Nurses. ICNP ${ }^{\circledR}$ Translations [homepage] 2014 [updated on 2013 Oct.; cited 2014 May 10]. Available from:file:///C:/ Users/2141494/Documents/icnp-Brazil-Portuguese_translation.pdf.

7. Conselho Internacional de Enfermeiros. Classificação Internacional para a Prática de Enfermagem- versão 2.0. Tradução: Heimar de Fátima Marin. São Paulo: Algol Editora; 2011.

8. Leal T. A CIPE e a Visibilidade da Enfermagem: Mitos e Realidades. Loures: Lusociência; 2006.

9. Alexandre NMC, Coluci MZO. Validade de conteúdo nos processos de construção e adaptação de instrumentos de medidas. Ciências \& Saúde Coletiva [Internet] 2011 [cited 2014 jun 23]; 16(7):3061-68. Available from: http://www.scielo. $\mathrm{br} / \mathrm{pdf} / \mathrm{csc} / \mathrm{v} 16 \mathrm{n} 7 / 06 . \mathrm{pdf}$

10. Brasil. Resolução n. 466, de 12 de dezembro de 2012. Dispõe sobre diretrizes e normas regulamentadoras de pesquisas envolvendo seres humanos. Diário Oficial [da] República Federativa do Brasil. 2012 Dec 12; Seção 1. p.59-62

11. Oliveira PB, Tavares DMS. Health conditions of elderly residents in Long-stay Institution second basic human needs. Rev bras enferm [Internet] 2014 Apr [cited 2014 jun 23]; 67(2): 241-246. Available from: http://www.ncbi.nlm.nih.gov/ pubmed/24861067

12. Garbaccio JL, Ferreira AD. Diagnósticos de enfermagem em uma instituição de longa permanência para idosos. R Enferm Cent O Min [Internet] 2012 sept/dec [cited 2014 jun 23]; 2(3):303-13. 
Available from: http://www.seer.ufsj.edu.br/ index.php/recom/article/view/218/345

13. Rocha LS, Souza EMS, Rozendo CA. Basic human needs and nursing care dependency of institutionalized elders. Rev Eletr Enf [Internet] 2013 jul/ sept [cited 2013 out 27]; 15 (3):722-30. Available from:http://www.fen.ufg.br/revista/v15/n3/pdf/ v15n3a14.pdf

14. Sousa RM, Santana RF, Santo FHE, Almeida JG, Alves LAF. Diagnósticos de enfermagem identificados em idosos hospitalizados: associação com as síndromes geriátricas. Esc Anna Nery [Internet] 2010 Dec [cited 2014 jun 23]; 14(4): 732-41. Available from: http://www.scielo.br/pdf/ ean/v14n4/v14n4a12.pdf.

15. Gautério DP, Santos SSC; Silva BC, Cruz VD, Zortea B, Alves I. Sociodemographic profile, diagnoses and nursing care proposed for elderly in institutions that use several medicines. J Nurs Health. [Internet] 2013 Jul [cited 2014 jun 23]; 3(2): 182-94. Available from: http://periodicos.ufpel. edu.br/ojs2/index.php/enfermagem/article/ viewFile/3713/3240

16. Silva LC, Dias FA, Andrade EV, Luiz RB, Mattia AL, Barbosa MH. Impaired physical mobility in institutionalized elderly. J res fundam care online [Internet] 2013 jul/set [cited 2014 jun 23]. 5(3):346-353. Available from: http://www.seer.unirio.br/index. php/cuidadofundamental/article/view/2133

17. Freitas LDO, Waldman BF. O processo de enveIhecimento da pele do idoso: diagnósticos e intervenções de enfermagem. Estud. interdiscipl. envelhec. [Internet] 2011. [cited 2014 jun 23]; 16 (esp): 485-497. Available from: http:// seer.ufrgs.br/index.php/RevEnvelhecer/article/ view/17924/16315

18. Cavalcanti ACD, Pereira JMV. Nursing diagnoses of patients with heart failure: an integrative review. Online brazj nurs [internet]. 2014 Mar [cited 2015 jun 5]; 13 (1):113-125. Available from: http://www. objnursing.uff.br/index.php/nursing/article/ view/3916

19. Saldanha EA, Silva FBBL, Sá JD, Fernandes MICD, Lira ALBC, Lopes MVO. Defining characteristics present in patients receiving post-operatory care after prostatectomy: a transversal study. Online braz j nurs [Internet]. 2013 Sept [cited 2015 jun 5];12 (2): 442-50. Available from:http://www. objnursing.uff.br/index.php/nursing/article/ view/4072

All authors participated in the phases of this publication in one or more of the following steps, in According to the recommendations of the International Committee of Medical Journal Editors (ICMJE, 2013): (a) substantial involvement in the planning or preparation of the manuscript or in the collection, analysis or interpretation of data; (b) preparation of the manuscript or conducting critical revision of intellectual content; (c) approval of the versión submitted of this manuscript. All authors declare for the appropriate purposes that the responsibilities related to all aspects of the manuscript submitted to OBJN are yours. They ensure that issues related to the accuracy or integrity of any part of the article were properly investigated and resolved. Therefore, they exempt the OBJN of any participation whatsoever in any imbroglios concerning the content under consideration. All authors declare that they have no conflict of interest of financial or personal nature concerning this manuscript which may influence the writing and/or interpretation of the findings. This statement has been digitally signed by all authors as recommended by the ICMJE, whose model is available in http://www. objnursing.uff.br/normas/DUDE_eng_13-06-2013.pdf

Received: 02/02/2015

Revised: 04/06/2015

Approved: 04/14/2015 
Oliveira JMM, Nóbrega MML, Oliveira JS. Nursing Diagnosis and Results for the Institutionalized Elderly: A Methodological 120 Study. Online braz j nurs [internet] 2015 Mar [cited year month day]; 14 (2):110-20. Available from: http://www.objnursing uff.br/index.php/nursing/article/view/5151 